\title{
ANALISIS TEKNIK BERNYANYI DIANA DAMRAU PADA \\ OPERA "THE MAGIC FLUTE ARIA QUEEN OF THE NIGHT” KARYA WOLFGANG AMADEUS MOZART
}

\author{
DEDI BENSAMAS LUMBAN GAOL \\ Prodi PendidikanMusik
}

\begin{abstract}
This study aims to analyze, Technique of Singing Diana Damrau oin Opera The Magic Flute Aria Queen Of The Night Works Wolfgang Amadeus Mozart. The purpose of this research is to know Technique of Singing, how to interpret and artistic overall Diana Damrau sing Opera The Magic Flute Aria Queen Of The Night.

The theory used is analyze, vocal technique, sound processing, sound formation, breathing, frasering, head voice, powering, vibrato, interpretation, singing, opera, aria,

The method used in this research is qualitative descriptive method, namely a research method that aims to describe in detail and clearly about a phenomenon that became the focus of research. This research is a qualitative descriptive laboratory works, thus this research is held in the laboratory of sendratasik music education program of state university of Negeri Medan. The results showed that Diana Damrau sang aria by using singing technique that is base of vocal technique. The achievement of singing technique has been applied verry well, where the singging technique is articulation, breathing, posture, resonance, vibrato, intonation. This factor becomes the main point that from the analysis, it has a verry high singing technique singing aria Queen Of The Night. Diana Damrau had application interpreation that is, the dynamics of $m p, m f, f, f f, f f$, aksen, sfz, fp, cressendo, descressendo. Tempo allegro assai, ad libitum, allargando.Style singging marcatto, alla marcia, legato, recitaive, ekspreso, stacatto, sustenuto, emozione. Angry authoritarian, direspectful and desire is an expression Diana to sing the aria. On the basis of it can be started that the overall appearance of Diana Damrau is interconnected to build on the builder's point to make the appearance of Diana Damrau towards spectaculer.
\end{abstract}

Keywords: analysis, singing technique, Diana Damrau, Aria Queen Of The Night.

\section{PENDAHULUAN}

\section{A. Latar Belakang Masalah}

Bernyanyi merupakan

serangkaian kegiatan untuk megungkapkan ekspresi lewat melodi dalam nyanyian. Teknik vokal adalah merupakan hal mendasar yang harus dikuasai oleh seorang penyanyi.. 
Menganalisis adalah sebuah upaya dan proses mengamati, mempelajari dan menyelidiki secara cermat suatu masalah untuk mengetahui dasar dan unsur-unsur yang terkandung dalam sebuah objek yang diteliti sehingga dapat dicari pemecahan masalahnya.

Teknik bernyanyi merupakan metode atau cara yang dilakukan dengan langkah-langkah teratur sehingga mencapai tujuan yang baik. Teknik atau metode bernyanyi jika dilakukan dengan baik maka akan menghasilkan suara yang berkualitas.

Opera adalah salah satu pertunjukkan musik dan vokal yang dianggap musik serius karena membutuhkan keahlian dalam bidang bernyanyi klasik sekaligus berdrama. Mahakarya opera terdiri dari bagianbagian potongan yang apabila dipisah, akan terlihat sebuah aria yang merupakan bagian atau potongan dari opera. Banoe (2003:30) mengatakan "Aria adalah nyanyian-nyanyian tunggal dalam sebuah adegan opera atau oratorio".

Diana Damrau adalah seorang penyanyi opera yang sangat berpengaruh membawakan aria
Queen Of The Night karya Wolfgang Amadeus Mozart. Kemampuan teknik bernyanyi Diana Damrau membawakan Aria Queen Of The Night, menghantarkan Diana Damrau tampil megah di acara besar opera antara lain, Covent Garden, the Salzburg Festival, the Vienna State Opera, Oper Frankfurt, the Bavaria State Opera dan lainnya (https://en.m.wikipedia.org/w).

Interpretasi Diana Damrau sangat berbeda dan selalu berkaitan dengan seluruh penampilan Diana Damrau.Inilah yang menjadikan Diana Damrau sukses masuk dari setiap karya yang telah dibawakannya, tidak terkecuali aria Queen Of The Night karya Wolfgang Amadeus Mozart.

Keseluruhan penampilan atau artistic overall merupakan bagian akhir yang menjadi poin penutup dalam pengemasan suatu penampilan aria maupun opera.

Kemampuan teknik bernyanyi, intepretasi serta artistic overall/keseluruhan penampilan Diana Damrau inilah yang membuat letak keunikan-keunikan yang ada pada salah satu karya Wolfgang 
Amadeus Mozart yang berjudul opera

The Magic Flute aria Queen Of The Night. Oleh karena itu peneliti terdorong untuk melakukan penelitian yang berjudul "Analisis Teknik Bernyanyi Diana Damrau Pada Opera The Magic Flute Aria Queen Of The Night Karya Wolfgang Amadeus Mozart”.

\section{Tujuan Penelitian}

1 Untuk mengetahui teknik bernyanyi Diana Damrau membawakan opera The Magic Flute aria Queen Of The Night.

2 Untuk mengetahui interpretasi bernyanyi Diana Damrau membawakan aria Queen Of The Night.

3 Untuk mengetahui keseluruhan penampilan/artistic overall Diana Damrau membawakan aria Queen Of The Night.

\section{B. LANDASAN TEORI}

Landasan teoritis menurut Wiersme (1986) dalam buku Sugiyono (2016:52) menyatakan bahwa " A theory os a generalization or series of generalization by which we attempt to explain some phenomena in a systematic manner",

\section{Teori Analisis}

Henien (2012:11) menyatakan bahwa "To analyze a piece of music is to advance an interpretation of it's charateristic, distinctive, and significant features, drawing on sometimes extending the body of music theory in the process".

\section{Teori Teknik}

Teknik merupakan cara-cara yang digeneralisasikan dengan baik agar dapat diterima atau digunakan secara sama dalam satu bidang disiplin dan praktek.

\section{a. Teknik Vokal}

Rundus mengatakan (2015:3) "Singers can only be authentically emotional when they are secure in their technique, and that security only come with practice".
a) Sikap Badan 
Menurut Christy (1975:33) mengatakan bahwa "Posture is the third great fundamental in singing. Good posture is not only vital for control in singging but also necessary for attractive personality and sound health as well".

\section{1) Sikap Berdiri}

Christy (1975:36) mengatakan "Chest comfotably high; spin and neck straight with head level; weight slightly forward on toes with one, foot somewhat in advance of the other hands relaxed and helds easly at papee waist level". Hal ini diperkuat dengan pernyataan Phillips (2011:27) mengatakan: "To sing efficiently, you need to line up all your body parts and get them ready to do their job with as little tension as possible. If you're slumped over, you have more trouble taking the breath you need to sing, because posture and tension directly affect the muscles".

\section{2) Sikap Duduk}

Christy

menyatakan: "Trunk of body leaned slightly forward away from chair back; hips back; spine and neck straight with head level; slight weight on toes; hands resting easly on lap".

b) Pembentukan Suara

$$
\text { Menurut Pramayuda }
$$
(2010:70) "Seorang penyanyi dapat dikatakan baik jika melalui proses pembentukan suara, hal ini berkesinambungan dan memerlukan waktu latihan yang cukup untuk mendapatkan suara yang berkualitas".

1) Pita Suara

Menurut Putra

(2006:127) bahwa:"Pita Suara atau plica vocalismerupakan sumber bunyi paling utama dan letaknya di kotak suara larynx, fungsinya sama seperti senar pada gitar atau biola, dimana pita suara diibaratkan dengan dawai atau senarnya, nafas identik dengan alat geseknya, dan resonator leher ibarat tangan yang menyinergikan gesekan antara keduanya sehingga menghasilkan bunyi.

2) Alat Pernafasan Linggono mengatakan "Suara yang dimiliki oleh seorang penyanyi, bersumber 
dari selaput suara yang terdapat pada pangkal tenggorok serta didukung oleh organ-organ lain yang ada disekitarnya".

\section{3) Rongga-rongga Resonansi}

Kikuchi (2006:2) mengatakan bahwa: "The resonator is also different for each instrument. For the voice it is the throat, mouth and nasal passages. In learning how to sing we must master techniques for controlling all three elements. We control the energy source through our breathing mechanism (abdominal muscles). We control the vibrator to make specific pitches as required by the music. We control the resonator to produce beautiful vibrant tones, good vowels and correctly execute consonants".

4) Organ-organ Pengolahan Suara.

Organ-organ pengolahan suara adalah bagian dalam mulut yang dapat membentuk vokal dengan baik.Bagian organ-organ pengolahan suara yaitu bibir, lidah, anak lidah, langit-langit, gigi atas dan gigi bawah.

$$
\begin{aligned}
& \text { c) Pengolahan Suara } \\
& \text { Linggono }
\end{aligned}
$$
mengatakan "Bentuk atau sikap mulut sewaktu menyanyi sangat mempengaruhi pembentukan nada yang dihasilkan. Kesalahan umum yang terjadi pada awal pelajaran menyanyi adalah bahwa mereka tidak bisa membuka mulutnya, sehingga suara yang dihasilkan kurang jelas". Adapun pengolahan suara yaitu olah Vokal atau pengucapan A, I, U, E, O

d) Pernafasan

Phillips (2011:39) mengatakan "Breathing in this manner gives you the breath control you need to sing efficiently. However, because controlled breathing doesn't come naturally, you need to train your body to breathe for singing".

Berdasarkan dari pendapat tersebut bahwa pernafasan diafragma adalah pernafasan paling baik dan efisien untuk digunakan dalam bernyanyi, karena udara yang digunakan akan mudah diatur pemakaiannya. Hal ini diperkuat oleh Pramayuda (2010:67-68) bahwa: "Pernafasan diafragma merupakan 
pernafasan yang menarik/mengambil atau mengambil kekuatan napas untuk mengisi paru-paru dengan mengembangkan rongga perut atau diafragma, yang juga diikuti dengan mengembangkan tulang rusuk.

e) Resonansi

$$
\text { Pramayuda }
$$

mengatakan "Resonansi adalah upaya untuk membuat suara bergema/bergaung indah, bukan hanya sekedar kuat atau keras seperti berteriak. Atau dengan kata lain, bagaimana memperluas wilayah bunyi yang ditimbulkan geteran. Gema itu harus terdengar indah dan teratur, sehingga apa yang diucapkan dapat dimengerti oleh pendengar".

\section{f) Frashering}

Menurut Yonathan (2013:73) "Frashering adalah pemenggalan kalimat musik menjadi bagian-bagian yang lebih pendek, tetapi tetap mempunyai kesatuan arti”.

\section{g) Teknik Head Voice} Phillips menyatakan "The higher part of your singing voice is called head voice because most people feel the vibrations in their head or skull while singing in head voice. Having a head voice for singing is necessary to access those really high notes in the song”.

h) Teknik Powering Rudy (2008:81-82)“Power suara adalah suatu tenaga yang dipergunakan untuk menyalurkan dan mengeluarkan suara.Power suara sangatlah penting peranannya dalam bernyanyi.Karena dengan power, suara yang dihasilkan akan sangat berkualitas, dan bisa membuat lagu yang dinyanyikan lebih bertenaga, berkarakter dan menjadi hidup, sehingga mampu menggerakkan dan menyentuh hati para penontonnya, dan selanjutnya akan menarik animo masyarakat".

i) Vibrato

Phillips (2011:81) mengatakan "Singers who have good coordination of breath and open space usually have vibrato. Think of a singer (probably someone you've heard singing opera or classical music) who 
makes a huge sound when singing. Now imitate that singer".

$$
\begin{aligned}
& \text { j) Interpretasi } \\
& \text { Hendrix }
\end{aligned}
$$
mengatakan "Interpretation is the most critical ingredient for fine singing. It is the life force breathed into the skeleton and musculature of a musical work. It unites the work from beginning to end. It gives variety to a beautiful voice, making it possible to hold the public's interest. It fuels the body with instructions from the imagination to stand in a certain way, to have a certain facial expression, or to color or expand a sound in a specific way".

Adapun bagian dari interpertasi terdiri atas dinamika, tempo, gaya dan ekspresi mimik wajah.

\section{Teori Bernyanyi}

The act of singing is probably the oldest form of music making, because it seems to come naturally to practically everyone(Kikuchi, 2006:1). Dengan kata lain benyanyi merupakan salah satu cara setiap manusia dalam mengungkapkan pikiran serta perasaanya melalui bunyi yang bersumber dari organorgan pembentuk suara pada tubuhnya sendiri dengan melafalkan syair, nada, ritme dan melodi tertentu hingga membentuk harmoni.

\section{Opera}

Opera adalah drama musik dari istilah Italia yaitu drama per la musica, mulai dikenal di Italia sekittar tahun 1600. Opera juga diistilahkan bagi organisasi atau penyelenggara opera seperti: Vienna state opera, tetapi dapat pula diistilahkan bagi gedung tempat pementasan opera (Banoe, 2003:307)". Hal ini diperkuat dengan pendapat Sandgren (2005:1) yang mengatakan bahwa "Opera developed early in 1600s in Italy, animated by the Renaissance spirit. This new art form combined words, music and drama, a style that basically remains the same even today. Today's major opera works performed on stages around the world originate from the 18th and 19th century. An opera singer's highly sophisticated vocal performance is still essential to the operatic performance. Opera singers are challenged to fulfil the artistic 
values written in the musical scores and at the same time excel in their individual expression".

\section{Teori Aria}

Prier

(2004:147)

mengatakan"Aria adalah sebuah olah vokal, biasanya dengan iringan orkes dalam bentuk tertutup (dengan kalimat-kalimat) namun lebih besar daripada bentuk lagu. Kelebihan ini nampak dalam panjangnya lagu maupun dalam mutu komposisi.Sebenarnya tidak ada bentuk tetap untuk aria.Memang, aria sering berdasarkan bentuk lagu dua atau tiga bagian; namun ada juga aria dalam bentuk rondo bahkan bentuk sonata".

\section{METODOLOGI PENELITIAN}

\section{A. Lokasi dan Waktu Penelitian}

\section{Lokasi Penelitian}

Penelitian ini dilakukan ddi Laboratorium Senratasik Prodi Pendidikan Musik.

\section{Waktu Penelitian}

Waktu yang akan digunakan dalam pelaksanaan peneliitian ini dimulai dari bulan April 2018 sampai dengan Mei 2018.

\section{B. Populasi dan Sampel}

\section{Populasi}

Sugiyono

(2016:215)

mengatakan bahwa"Dalam penelitian kualitatif tidak menggunakan istilah populasi, tetapi oleh Sspradley dinamakan "social situation" atau situasi sosial yang terdiri atas tiga elemen yaitu: tempat (place), pelaku (actors), dan aktivitas (activity) yang berinteraksi secara sinergis".

Berdasarkan pendapat diatas maka penelitian ini tidak menggunakan populasi.

\section{Sampel}

Sampel pada penelitian ini adalah teknik bernyanyi Diana Damrau pada aria Queen of The Night.

\section{Teknik Pengumpulan Data}

\section{Observasi}

Sesuai pendapat Hadeli (2006:85) mengatakan bahwa: "penelitian dengan cara menggadakan pengamatan terhadap objek baik secara langsung maupun tidak 
langsug, menggunakan teknik yang disebut dengan pengamatan atau observation".

\section{Studi Kepustakaan}

Penulis mencari dan membaca beberapa literatur seperti buku dan artikelnyang relevan dengan pokok yang akan dibahas. Dengan adanya sumber-sumber pustaka tersebut maka dapat diperoleh banyak informasi yang membantu penulis dalam mengerjakan penelitian ini.

\section{Studi Dokumentasi}

Studi Dekumentasi dilakukan guna untuk memperkuat dugaan sementara dan akan dijadikan sebagai fakat baru dari dugaan tersebut.

\section{Kerja Laboratorium}

Penelitian ini mengambil kerja laboratorium untuk memfokuskan penelitian terhadap objek yang diteliti. Kerja laboratorium yang dilakukan yaitu fokus pada partitur, audio dan video Diana Damrau membawakan aria Queen of The Night.

\section{Teknik Analisis Data}

Berdasarkan pendapat, maka tahapan analisis data dalam penelitian ini akan diupayakan untuk memperdalam atau menginterpretasi data secara spesifik dalam rangka mendeskripsikan tujuan penelitian.

\section{ISI}

\section{A. Wolfgang Amadeus Mozart}

Mozart adalah seorang komposer musik yang memiliki kontribusi sangat besar dalam perkembangan musik Eropa. Wolfgang Amadeus Mozart adalah anak ketujuh dari suami-istri keluarga besar Mozart, ia lahir di Salzburg, Austria, pada tanggal 27 Januari 1756.Opera The Magic Flute merupakan karya opera yang lahir dari tangan seorang Wolfgang Amadeus Mozart. Karyakarya Mozart sangat identik dengan gaya Italia.

\section{B. Opera The Magic Flute}

The Magic Flute atau dalam bahasa Jermannya Die Zauberflote adalah opera ke dua yang telah dilahirkan oleh Wolfgang Amadeus Mozart dalam Libreto (teks musik) 
Jerman

oleh

Emanuel

Schikaneder.Karya ini sangat epik dan terkenal lewat komposisi yang telah disusun oleh W.A Mozart dalam karya tersebut.Karya ini pertama kali ditampilkan pada 30 September 1791 di Schikaneder's theatre, kemudian ditampilkan di Freihaus - Theater auf der Wieden-Vienna, hanya dua bulan setelah kematian W.A Mozart.

\section{Diana Damrau}

Diana Damrau adalah seorang penyanyi soprano yang lahir pada tanggal 31 Mei 1971, ia merupakan seorang penyanyi opera asal Jerman yang tergabung dalam Kammersängerin of the Bavarian State Opera. Penghargaan dalam bidang opera telah diraihnya sejak belajar studi khusus vokal klasik di Edema Art.

Kemampuan teknik bernyanyi

Diana Damrau membawakan Aria Queen Of The Night, menghantarkan Diana Damrau tampil megah diacara besar Opera antara lain, Covent Garden, the Salzburg Festival, the Vienna State Opera, Oper Frankfurt, the Bavaria State Opera dan lainnya.

\section{Aria Queen Of The Night}

Queen Of The Night merupakan bagian aria yang terambil dari opera The Magic Flute. Aria Queen OfThe Night menggambarkan seorang ratu yang terpuruk dalam kehancuran sehingga membekas dalam hati dan berujung pada pembalasan dendam.

Aria Queen Of The Night dinyanyikan dengan tempo Allegro assai (sangat cepat) dan jumlah birama yang terdapat pada aria terdiri dari 99 bar yang menggunkan satu tanda sukat 4/4. Aria Queen Of The Night memiliki jangkauan nada yang sangat tinggi, oleh karena itu aria Queen Of The Night dibawakan dan dinyanyikan oleh penyanyi soprano. Adapun Wilayah nada pada arianQueen Of The Night adalah F4 nada terendah dan F6 nada tertinggi.

\section{E. Teknik Bernyanyi Diana Damrau Membawakan Opera The Magic Flute Aria Queen Of The Night.}

Kegiatan analisis dalam penelitian ini akan dimulai dengan mendengarkan serta memperhatikan secara detail video penampilan Diana 
Damrau membawakan aria Queen $O f$ The Night karya Wolfgang Amadeus Mozart yang berdurasi selama 05:24 secara bertahap dan berulang.

\section{Teknik Vokal}

Keindahan teknik bernyanyi

Diana Damrau tidak terlepas dari teknik vokal dan teknik vokal dasar.Teknik vokal dasar seorang penyanyi opera Diana Damrau membuatnya mampu mengimplemetasikan setiap penampilannya melalui teknik vokal yang sulit dan tinggi.Seorang penyanyi opera dituntut memiliki kemampuan bernyanyi yang sangat tinggi untuk membawakan opera ataupun aria.

a. Teknik Sikap Badan

Sikap badan Diana Damrau saat membawakan aria Queen Of The Night sangat tegas.Dalam penampilannya Diana Damrau dituntut untuk membawakan aria tersebut dengan sikap badan yang berbeda, berdasarkan properti yang digunakan Diana Damaru untuk memperkuat penampilannya.

\section{1) Sikap Berdiri}

Pengaplikasian sikap berdiri yang baik sangat berpengaruh besar terhadap vokal dan teknik diafragma tanpa terhalang dengan tekanan otototot leher dan perut.Hal ini terlihat dalam video penampilan yang berdurasi 05:24 tersebut, bahwa Diana Damrau menjadikan pondasi sikap berdirinya menjadi acuan meningkatkan kepercayaan diri dan teknik diafragma yang sangat baik.Pada menit ke 01:27 sebelum memulai menyanyikan aria, Diana Damrau perlahan telah mengaplikasikan teknik sikap berdiri untuk meningkatkan penampilan dan membantunya dalam memberikan aba-aba baginya untuk memulai bernyanyi.

Pada menit ke 02:19 dan birama 1, Diana Damrau telah memulai menyanyikan aria Queen $O f$ The Night. Sikap badan yang sudah baik memberikan Diana kekuatan penuh untuk mendorong kekuatan diafragma.Diana Damrau telah mengatur seluruh bagian tubuh lurus sejajar dan membiarkan tubuhnya melakukan tugas dengan semaksimal 
mungkin, sehingga berdiri dengan memposisikan dada sedikit dibusungkan memberi ruang bagi diafragma agar mendapat volume udara yang cukup banyak.Hal ini didukung dengan posisi Diana Damrau yang memperlihatkan posisi berdiri tampak samping pada menit ke 02:49 atau birama 18.Struktur tubuh yang baik terlihta jelas pada bagian ini, dimana Diana membusungkan dada guna untuk menambah ruang diafragma agar dapat menyanyikan jumlah birama yang panjang serta power suara yang baik dan stabil.Berikut gambar tampak samping sikap berdiri Diana Damrau.

Diana Damrau menutup penampilannya dengan sangat baik dan tidak luput poin sikap berdiri yang baik. Pada menit ke 04.57 birama 88, Diana Damrau siap menutup penampilannya tanpa mengurangi konsistensi sikap berdiri yang telah ia mulai di awal. Komitmen awal yang dipegang oleh Diana untuk memperkuat sikap berdiri membuatnya sangat efisien untuk berlakon, berekspresi dan teknik bernyanyi dalam penampilannya.

2) Sikap Duduk

Pada menit 04:02 menunjukkan bahwa Diana sedang melakukan posisi awal untuk melakukan posisi sikap duduk.Badan yang tegak sejajar serta dada sedikit dibusungkan kedepan menjadi awal Diana untuk melakukan sikap duduk. Pada menit 04:16 dan 04:37 serta birama 64-86, Diana melakukan sikap duduk dan melakukan gerakan terhadap lawan tokohnya.Hasil produksi suara yang dihasilkan tetap stabil dan semakin Diana mendorong kekuatan diafragmanya semakin tegak badan Diana untuk menyokong suaranya.

\section{b. Teknik Pembentukan Suara} Hasil yang telah dicapai Diana Damrau berkesinambungan dan memerlukan waktu latihan yang cukup untuk mendapatkan suara yang berkualitas.

1) Pita Suara

Hasil dari suara Diana

Damrau adalah nada yaitu suara 
manusia sedang bernyanyi yang terdengar nyaring karena selaput suara Diana Damrau meregang rata dan seimbang, produksi suara yang dihasilkan juga teratur dan sesuai dengan yang dibutuhkan oleh Diana Damrau sebagai penyanyi opera.

2) Teknik Ronga-rongga Resonansi.

Resonansi yang dikeluarkan Diana Damrau membuat suaranya bergema/bergaung indah, bukan hanya sekedar kuat atau keras seperti berteriak.Hasil dari rongga resonansi tersebut dikarenakan udara yang telah di arahkan menuju resonansi tidak sesegera mungkin keluar, melainkan udara tersebut akan keluar dengan perlahan dan menghasilkan udara hangat.

\section{3) Teknik Pengolahan Suara} Berdasarkan video penampilan Diana Damrau, bahwa olah vokal yang di aplikasikan oleh Diana Damrau sangat baik, hal ini sejalan dengan diksi yang terdengar sangat jelas dalam video, sehingga para pendengar dapat mengetahui olah vokal apa yang sedang dinyanyikan oleh Diana Damrau. Ketegasan bentuk vokal yang dilakukan oleh Diana Damrau pada olah vokal a,i,u,e,o semakin menguatkan karakteristik dan pesan tokoh Diana Damrau pada aria Queen Of The Night.

4) Teknik Pernafasan Diafragma. Dalam implementasi teknik pernapasan, Diana Damrau menggunakan pernafasan diafragma.Kontraksi pernafasan Diana Damarau dalam video yang berdurasi 05:24 menuju pada pernafasan Diafrgama.Dari hasil penelitian dan analisis terhadap video penampilan Diana Damrau pada menit 02:51 birama 24, saat kamera mendekat terlihat kontraksi diafragma Diana Damrau.

Volume diafragma Diana Damrau sangat terlihat dengan jelas, ketika menarik dan melakukan kontraksi pernafasan diafragma.Hal ini menjadi dasar pokok bagi Diana Damrau untuk mengontrol diafragma dengan seperlunya.Pada durasi 04:06 kemampuan diafragma Diana Damrau sangat diuji dan Diana sanggup melakukan teknik diafragma dengan 
jumlah birama yang cukup panjang tanpa terputus, melodi yang konstan dan bahkan Diana Damrau menunjukkan kemampuan diafragmanya dengan posisi duduk yang sangat sulit untuk dilakukan bagi penyanyi opera.Faktor inilah yang semakin menguatkan karakter seorang Diana Damrau sebagai penyanyi opera.

\section{5) Teknik Frashering.}

Berdasarkan sumber video penampilan Diana Damrau yang berdurasi 05:24 dalam bentuk tabel. Hal ini menunjukkan bahwa Diana Damrau meletakkan bentuk kalimat yang tepat, sehingga bentuk asli kalimat dan makna aria Queen Of The Night tetap memiliki keutuhan sesuai dengan bentuk musik yang berlaku pada aria Queen Of The Night.

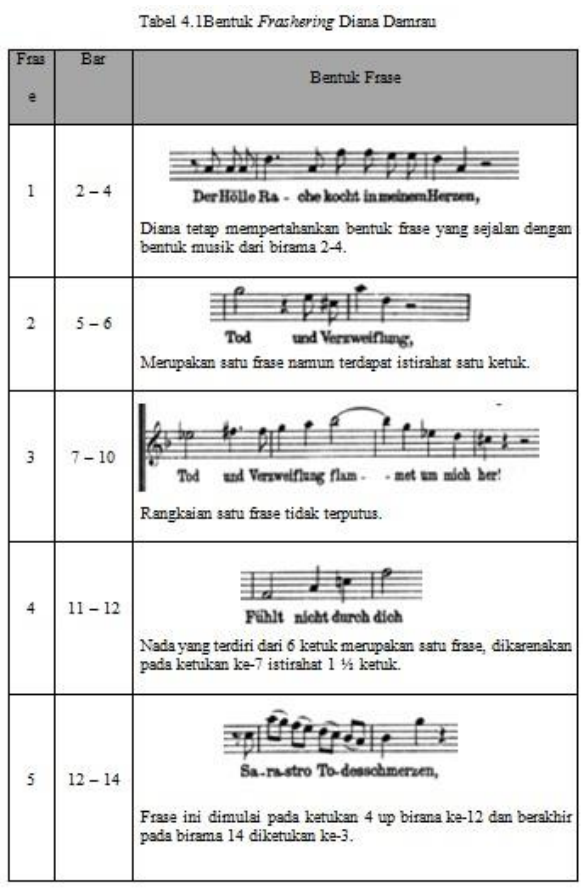

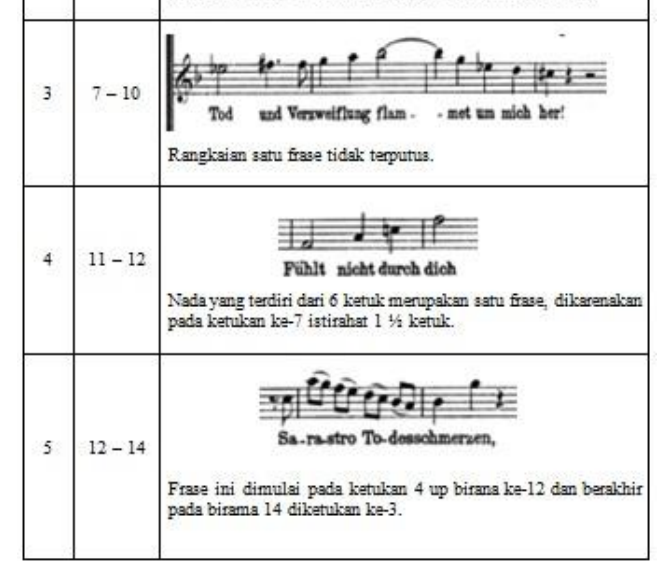


6) Teknik Head Voice.

Dari hasil penelitian bahwa

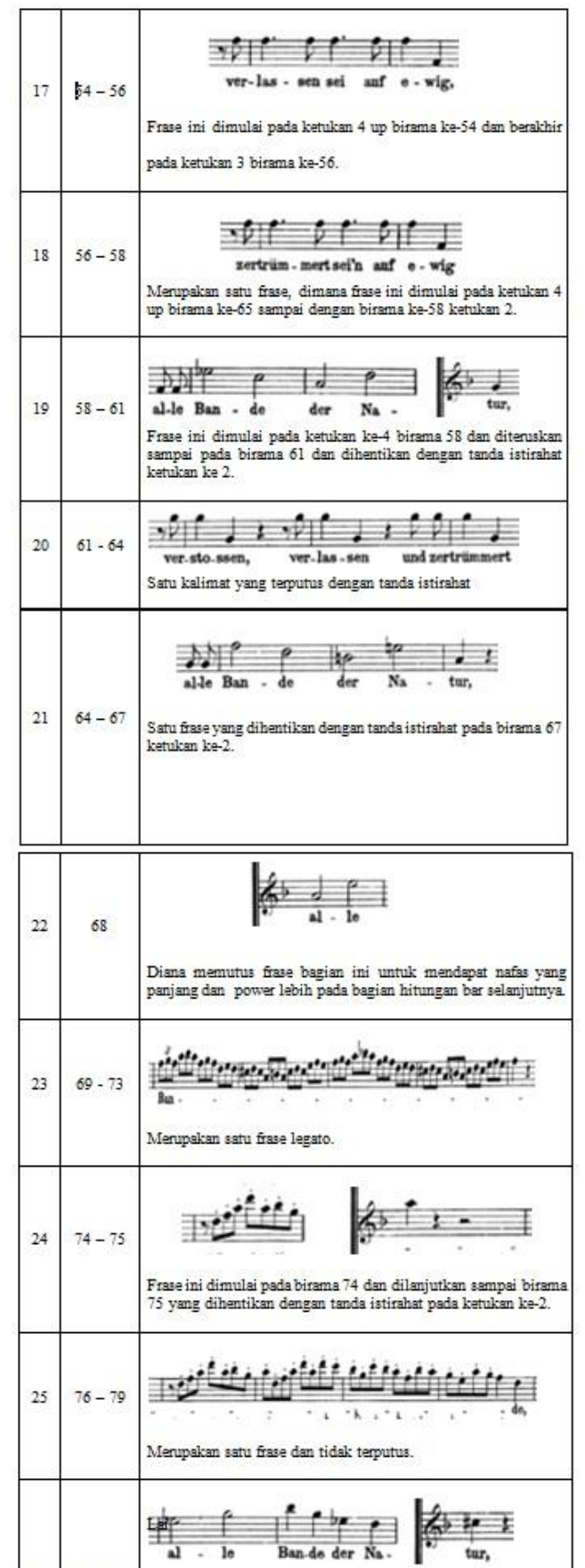

Diana Damrau melakukan teknik ini untuk mencapai nada-nada tinggi. Hal ini didukung dengan hasil produksi suara Diana Damrau menjangkau nada tinggi yang sangat jernih tanpa ada tekanan dari otot leher, sehingga Diana Damrau dengan mudah menggunakan register atas. Aria Queen Of The Night khususnya memiliki banyak wilayah nada yang sangat tingg, dan secara otomatis penyanyi aria Queen of The Night harus memiliki register atas yang sangat baik untuk mencapai nadanada tinggi.Adapun penggunaan teknik head voice terdapat pada bar 39- 42 dan terdengar jelas bahwa head voice sangat membantu suara untuk menggapai nada yang tinggi.

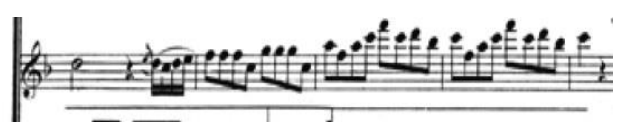


7) Teknik Powering.

Diana Damrau menyanyikan nada dengan kekuatan penuh bantuan oto-otot difragma. Pada bar 5, 8, 15 dan bar lainnya terdengar dengan jelas Diana Damrau sontak memberikan dorongan teknik powering untuk memperkuat makna lirik dan style singing Diana Damrau membawakan aria Queen of The Night.

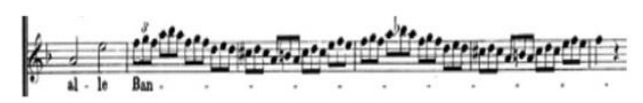

8) Teknik Vibrato.

Setelah mendengarkan video penampilan Diana Damrau pada aria Queen Of The Night, maka teknik vibrato yang digunakan dalam menyanyikan aria tersebut yaitu sebagai berikut : Adanya penekanan vibrato pada ketukan ke-1 pada birama $3,6,7,13,15,18,21,23,26$, $28,33,34,37,38,45,53,55,57,59$, 65, 80, 88, 89, 90 dan 94. Ketukan ke-3 dan ke-4 pada birama 8, 19, 33 dan 43. Teknik vibrato juga dipakai pada tanda legatura yang ada pada biarama 8 dan 90 .

\section{F. Interpretasi BernyanyiDiana Damrau Membawakan Aria Queen Of The Night.}

Salah satu cara yang dilakukan seorang penyanyi untuk menyampaikan maksud dan tujuan sebuah lagu yaitu dengan menggunakan teknik penjiwaan. Untuk mendapatkan hasil analisis yang baik maka melakukan riview ulang untuk menyamakan dengan karya utuh Wolgang Amadeus Mozart. Diana Damrau sangat baik sekali menempatkan interpretasi pada bagian aria Queen of The Nigh, sehingga suasan yang ditimbulkan oleh Diana semakin hidup dan pesan yang hendak disampaikan dapat terealisasikan dengan baik.

5. Dinamika 


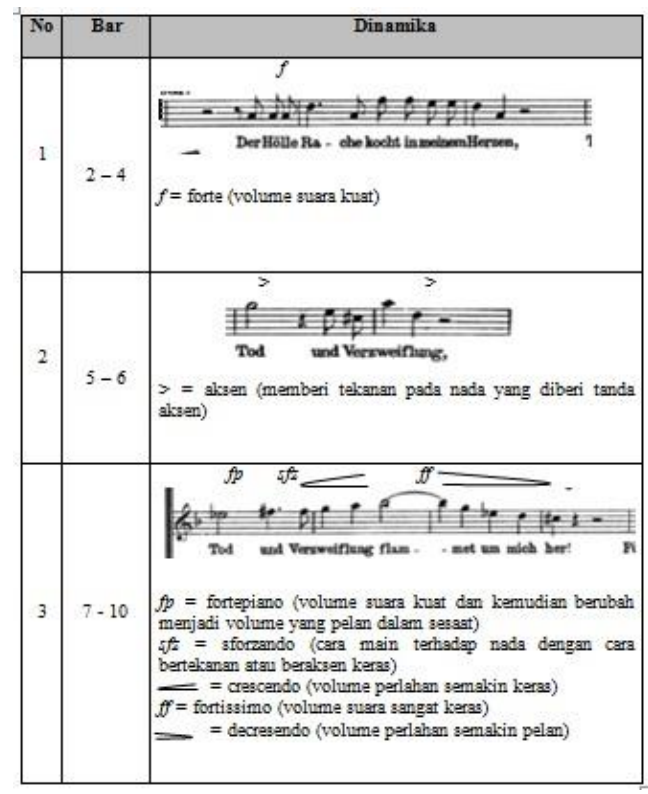

\begin{tabular}{|c|c|c|c|c|c|}
\hline \multirow[t]{2}{*}{4} & $17-20$ & 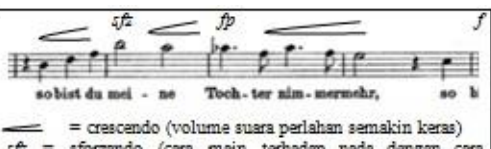 & & & \\
\hline & & $\begin{array}{l}\text { fft }=\text { sforzando (cara main terhadap nada dengan cara } \\
\text { bertekanan atsu beraksan keras) } \\
f p=\text { fortepiano (volume suara kuat dan kemudian berubah } \\
\text { menjadi volume yang pelan dalam sasaat) } \\
f=\text { forte (volume suara keras) }\end{array}$ & \multirow[t]{2}{*}{16} & \multirow[t]{2}{*}{$88-90$} &  \\
\hline \multirow[t]{2}{*}{5} & \multirow[t]{2}{*}{$21-22$} & \multirow{2}{*}{ L= crescando (volume suara perlahan semalkin keras) } & & & $\begin{array}{l}f=\text { forte (volume suars keras) } \\
f f=\text { fortesimo (volume suara angat keras) } \\
\text { fff }=\text { fortesisimo (volume suara sangat angat keras) }\end{array}$ \\
\hline & & & \multirow[b]{2}{*}{17} & \multirow[b]{2}{*}{94} & \multirow{2}{*}{$f=$ forte (volume suara keras) } \\
\hline 6 & $24-26$ & 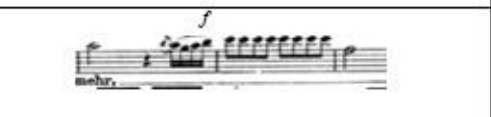 & & & \\
\hline
\end{tabular}

\section{Tempo}

\begin{tabular}{|c|c|c|}
\hline No & Bar & Tempo \\
\hline 1 & 1 & 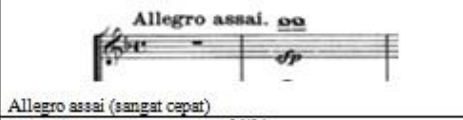 \\
\hline 2 & $84-85$ & ad libitum (menurut kehendals sendiri, bebas dari hitungan) \\
\hline
\end{tabular}

3. Gaya

\begin{tabular}{|c|c|c|}
\hline No & Bar & Gaya \\
\hline 1 & $2-3$ & $\begin{array}{l}\text { marcato (bertelsangn, cara main dengan derap langkah mirip } \\
\text { berbaris) } \\
\text { alla marcia (seperti mars, tempo berbaris) }\end{array}$ \\
\hline 2 & $7-10$ & $\begin{array}{l}\text { recitative expressivo } \\
\text { recitative (cara nyanyi dengan gaya pidato) } \\
\text { expressivo (sangat berelspresi) } \\
\text { legato (cara main sacara bersambung) }\end{array}$ \\
\hline
\end{tabular}




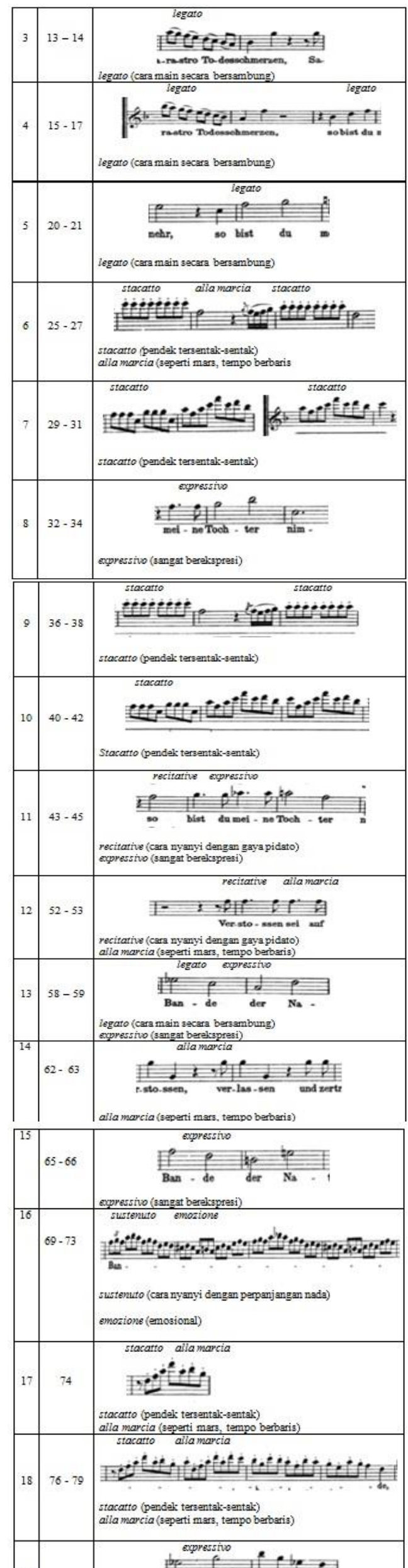

4. Ekspresi.

Secara keseluruhan ekspresi Diana Damrau sangat tegas, seakan menunjukkan karakter yang tegas layaknya seorang ratu yang memimpin sebuah kerajaan.Namun beberapa kali Diana Terlihat melemahkan ekspresi ketegasannya, guna masuk kepada ekspresi lainnya.

Saat Diana memulai bernyanyi pada menit 02:24, birama 7-12 Diana memunculkan ekspresi marah, seakan menekankan suatu hal kepada Pamina selaku putrinya untuk melakukan permintaan sang ratu. Hal ini berkaitan dengan makna lirik "Tod und Verzweiflung flammet um mich her!" yang artinya, kehancuran dan keputusasaan di dalam ku. Diana menunjukkan kepedihan mendalam lewat ekspresinya, bahwa dengan luka yang sangat mendalam ia memberi ketegasan kepada Pamina 
bahwa semua ini diakibatkan oleh Sarastro yang telah menghancurkan kerajaan mereka dan ayah di jadikan seorang.

$$
\text { Pada saat Diana }
$$

melakukan kegiatan bernyanyi menit 02:34, birama 13-16, Diana memunculkan ekspresi bersifat otoriter dengan menggunakan propreti, seakan semakin memaksa Pamina untuk memenuhi balas dedamnya. Ekpresi yang dikeluarkan oleh Diana Damrau diperkuat denga makna lirik "Fühlt nicht durch dich Sarastro Todesschmerzen" yang artinya, jika Sarastro tidak merasakan apa yang kamu rasa pahitnya kehancuran. Menggunakan makna tersebut Diana Damrau membuatnya menjadi poin penting untuk masuk dan mengikat lawan tokohnya yaitu Pamina. Diana kembali menegaskan apa yang telah meraka alami atas perbuatan jahat Sarastro kepada keluarga mereka.

Pada saat Diana melakukan kegiatan bernyanyi menit 02:46, birama 17-24 Diana memunculkan ekspresi yang menunjukkan tidak menghargai terhadap suatu hal dengan menggunakan postur tubuh yang dibusungkan kedepan, tangan yang ditekuk menujukkan kekuasaan dan wajah yang menunjukkan sikap ingin menghancurkan Sarastro. Hal ini sejalan dengan makna lirik "So bist du meine Tochter nimmermehr" yang artinya, nantinya kamu tidak lagi pernah menjadi putriku, kamu takkan kuanggap selamanya.

Kegiatan bernyanyi tetap
berlangsung dan Diana tetap
mempertahankan ekpresinya. Durasi
yang menunjukkan menit $04: 12$,
birama 68-74 Diana mulai
melemahkan ekspresi tidak menghargai dan mengalihkan pada ekspresi yang penuh harapan, dimana sang ratu berharap Pamina selaku putrinya dapat memenuhi permintaan ibunya untuk membunuh Sarastro dan dendam kerajaanya. Hal ini sejalan dengan makna lirik "Alle Bande der Natur, Wenn nicht durch dich! Sarastro wird erblassen!" yang artinya, Untuk semua hukum alam, jika tidak melalui kamu, Sarastro menjadi pudar! Seakan mati.Berdasarkan lirik serta, Diana sangat berharap bahwa apa yang telah disampaikannya terhadap Pamina 
untuk dipenuhi dan dijadikan sumpah bagi keluarganya.

\section{G. Keseluruhan Penampilan atau} Artistic OverallDiana Damrau Membawakan Aria Queen Of The Night.

Aria Queen of The Night menjadi titik pengakuan baginya sebagai penyanyi opera yang memiliki kemampuan sangat tinggi. Teknik bernyanyi Diana telah difikirkan secara matang sebelum mengaplikasikannya terhadap kegiatan benrnyayi.Dengan apresiasi para penonton memberikan tepuk tangan yang sangat megah telah menjadi bukti bahwa Diana Damrau berhasil masuk dan menghipnotis penoonton, dan sehingga para penonton sangat yakin memberi apresi paling besar dengan memberikan tepuk tangan yang kuat.

\section{PENUTUP}

Berdasarkan hasil penelitian
dan pembahasan tentang analisis
teknik bernyanyi Diana Damrau
membawakan aria Queen Of The
Night karya Wolfgang Amadeus

Berdasarkan hasil penelitian karya Wolfgang Amadeus
Mozart, maka dalam bab penutup ini akan diterangkan secara singkat mengenai kesimpulan dari penelitian ini.

1. Analisis teknik bernyanyi Diana Damrau membawakan aria Queen Of The Night dibawakan dengan iringan orkestra. Diana Damrau menyanyikan aria dengan menggunakan teknik bernyanyi yaitu dasar teknik vokal. Hal ini didukung dengan hasil analisis yang telah dipaparkan pada bab sebelumnya. Pencapaian Teknik Bernyanyi telah diaplikasikan Diana dengan sangat baik, dimana poin bernyanyi tersebut adalah artikulasi, penafasan, sikap badan, resonansi, vibrato, intonasi. Setiap aspek pembangun dalam bernyanyi dapat di aplikasikan oleh Diana Damrau dengan sangat baik. Kelebihan-kelibihan yang diampilkan Diana membuatnya menjadi penyanyi opera yang berbeda dari kebanyakan penyanyi opera lainnya. Kemampuan Diana Damrau 
dalam mengolah teknik

bernyanyi berbanding lurus

dengan iringan musik orkestra dari karya Wolfgang Amadeus

Mozart yang sangat spektakuler.

2. Interpretasi salah satu kegiatan yang dilakukan oleh Diana Damrau untuk menunjukkan kebolehannya dengan teknik vokal yang sangat tinggi. Diana mengaplikasikan dinamika $m p$, $m f, \quad f, \quad f f, \quad f f$, aksen, $s f z, f p$, cressendo, descressendo. Tempo allegro assai, ad libitum, allargando. Gaya marcatto, alla marcia, legato, recitaive, ekspreso, stacatto, sustenuto, emozione. Ekspresi tegas, otoriter, angkuh, berharap. Interpretasi inilah yang telah membangun hubungan watak dengan penampilan Diana Damrau membawakan aria Queen Of The Night.

3. Keseluruhan penampilan Diana Damrau sangat baik sekali. Setiap aspek pembangun teknik bernyanyi dapat direalisasikan dengan sangat baik oleh Diana Damrau membawakan aria Queen of The Night.
Berdasarkan hal itu dapat dinyatakan bahwa keseluruhan penampilan Diana Damrau saling berkaitan untuk membangun satu sama lain dan menjadi poin pembangun menjadikan penampilan Diana Damrau menuju spektakuler.

\section{DAFTAR PUSTAKA}

A Christy, Van. 1975. Expressive Singging volume dua. U.S.A: Ninth Printing.

Arikunto, Suharsimi. 2006. Prosedur Penelitian Suatu Pendekatan Praktik. Jakarta: PT Rineka Cipta.

Athouse, Jay. 2015. The Complete Choral Warm-UP Book. U.S.A: AlfredPublishing.

Busroh, Jamalus. 1992. Pendidikan Kesenian Musik I, Jakarta. Depdikbud.

Banoe, Pono. 2003. Kamus Musik. Yogyakarta: Penerbit Kanisius.

Burger, Birgitta. 2010. "Influence Of Musical Features On Characteristic OfMusic-Induced Movements". International Conference on MusicPerception and Cognition. Hlm. 425-428. 
Hendrix, Robin. 2013. How To Sing

Like A Great Singers. Prancis: France.

Hadeli. 2006. Metode Penelitian Kependidikan. Ciputat: PT Ciputat Press.

Kikuchi. 2006. Vocal Method Lesson. Pittburgh: Kikuchi Music.

Linggono.Budi.2008. Seni Musik Non Klasik. Jakarta: Depdikbud.

Moleong, Lexy J. 2009. Metodologi Penelitian Kualitatif. Bandung: PT RemajaRosdakarya.

McNeill, Rhoderick J. 1998. Sejarah Musik, Musik Awal Masa Yunani KunoSampai Akhir Masa Barok Tahin 0-1760. Jakarta: PT. BPK Gunung Mulia.

Putra, Esa, Adjie. 2006. 1001Jurus Mudah Bernyanyi. Bandung: Mizan Media.

Pramuyuda, Yudha. 2010. Buku Pintar Olah Vokal. Yogyakarta: BukuBiru.

Phillips, Pamelia S. 2011. Singing For Dummies 2nd Edition. Indiana: WileyPublishing.

Purwono, Joni. 2014. Penggunaan Media Audio-Visual Pada Mata PelajaranIlmu Pengetahuan Alam di Sekolah Menengah Pertama Negeri 1 Pacitan.Semarang: Universitas Negeri Semarang.
Prier, Edmund Sj, Karl. 2004. Ilmu Bentuk Musik (cetakan kedua). Yogyakarta:Pusat Musik Liturgi.

Rundus, Katharin. 2015. Cantabile Voice Class. U.S.A:

PavanePublishing.

Rudy MY. 2008. Panduan Olah Vokal. Yogyakarta: MedPress.

Santoso, Eko. 2008. Seni Teater. Jakarta: Direktorat.

Santoso, Eko. 2013. Pengetahuan Teater, Pementasan Teater dan Formula Dramaturgi. Jakarta: Direktorat.

Sugiyono. 2016. MetodePenelitian Kuantitatif, Kualitatif, dan $R \& D$. Bandung:Alfabeta

Sandgren, Maria. 2005. Becoming and Being An Opera Singer: Health,Personality, and Skills.Stockholm" Stockholm University.

Suroso. 2015. Drama, Teori dan Praktik Pementasan. Yogyakarta: ELMATERA.

Tohirin.2013. Metode Penelitian Kualitatif Dalam Pendidikan dan BimbinganKonseling. Jakarta: PT RajaGrafindo Persada.

Yonathan, Heri. 2013. PIP VOKAL. Jakarta: Depdikbud. 
1986. The Home Book of Musical

Knowledge. U.S.A: Copyright

Company.

https://en.m.wikipedia.org/w 